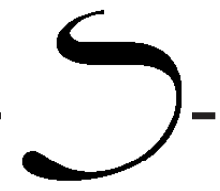

Капц И. В.

\title{
Внедрение в систему среднего профессионального образования компетентностного подхода*
}

Улучшение качества образования - одна из наиболее острых проблем не только России, но и всего мирового сообщества. Для её решения требуется модернизация содержания образования, пересмотр технологий образовательного процесса, пересмотр конечной цели образования. «Стратегия модернизации содержания образования» и «Концепция модернизации российского образования на период до 2010года» подчеркивают, что современное образование должно соотноситься с формированием и развитием ключевых компетенций как основы профессиональной мобильности [1].

Важнейшей составляющей системы российского образования является среднее профессионально-техническое образование, оно дает человеку возможность самоопределиться в профессиональной сфере, а так же умение проектировать свою учебу для достижения востребованных жизнью компетенций.

Одной из наиболее актуальных, малоисследованных педагогических проблем является проблема внедрения компетентностного подхода в процессе обучения специалистов среднего профессионального образования (СПО): целеполагание, отбор содержания образования, выбор методов, средств и организационных форм проектно-учебной деятельности, их влияние на формирование личностных качеств, социальное становление.

Формирование профессиональных компетенций направленно на реализацию единства научной и практической подготовки выпускников средних профессиональных учебных заведений, что должно способствовать их социальной и профессиональной адаптации в условиях быстро меняющегося окружения.

После присоединения России в 2003 г. к Болонскому процессу изменился подход к структуре и содержанию образования, так как основная идея вышеупомянутого проекта заключается во взаимном сближении структур профессионального образования европейских стран, в выработке единого подхода к оценке «качества» образовательных программ учебных заведений, а так же признания их дипломов.

Наиболее распространенная, действующая в нашей стране в настоящее время образовательная модель нацелена на усвоение субъектом обучения информации в виде теоретических конпетенций и практических умений, овладение которыми позволит быть профессионально успешным на протяжении всей жизни. Современный рынок труда предъявляет высокие требования не только к знаниям, умениям и навыкам, но и к компетентности работника. Эта тенденция особенно явно проявляется в тех областях профессиональной деятельности, где требуется постоянный учет изменений во внешней и внутренней среде.

* Материалы представлены научным руководителем - зав.кафедрой математики Таганрогского пед. института, профессором, доктором педагогических наук А.В. Тихоненко 
Основной идеей компетентностного подхода является формирование содержания образования в зависимости от предъявляемых требований общества, то есть от «ожидаемого результата». В содержание ключевых компетенций входят не только знания, но и готовность применять знания в различных производственных ситуациях, то есть использование так называемых «профессиональных компетенций».

Консолидированного мнения о сущностных характеристиках и объеме понятия «профессиональные компетенции» ещё не сложилось. Происходит путаница в терминологии, не разграничены объёмы понятий «ключевые навыки», «ключевые квалификации», «базовые навыки», «ключевые компетенции». В их дефинициях авторы в качестве сущностных выбирают те их характеристики, которые, по тем или иным причинам, считают наиболее важными. Одни авторы к компетентности относят - широкую общеобразовательную, политехническую и метакультурную осведомленность, другие - обозначают способности в области выполнения широкого спектра обобщенных действий - компетенций, третьи - характеризуют социально-профессиональные качества обучаемых и работников, называя их профессиональными компетенциями. Попытаемся внести ясность в некоторые из этих вопросов в рамках нашего исследования.

Компетентностный подход в сфере образования - явление сравнительно новое для отечественной педагогики. Его развитие связано с модернизацией российского образования и вхождения в мировую систему, что принципиально меняет цели образования.

Ранее цели образования определялись необходимостью формирования знаний, умений и навыков, которыми должен овладеть выпускник. Сегодня обществу нужны специалисты нового типа, готовые к включению в дальнейшую жизнедеятельность, способные практически решать встающие перед ними личные, общественные и профессиональные проблемы. Возникает противоречие между существующим содержанием обучения в учреждениях среднего профессионального образования и требованиями, предъявляемыми жизнью к подготовленному специалисту в практической деятельности. Решение поставленной проблемы зависит не только от полученных знаний, умений, навыков, но и дополнительных качеств личности, для обозначения которых широко употребляются понятия «компетенция» и «компетентность».

Введение этих понятий в педагогическую практику требует изменения содержания и методов образования, уточнения видов деятельности, которыми должны овладеть учащиеся к окончанию образования при изучении отдельных предметов.

Компетентностный подход постепенно переориентирует образовательную парадигму с преимущественной трансляцией знаний, формирования навыков на условия овладения комплексом компетенций, создающих потенциал выпускника для выживания и устойчивой жизнедеятельности в условиях современного многофакторного рыночно-экономического, информационно-коммуникационного насыщенного пространства. 
Устаревшее и перегруженное информацией содержание учебных предметов в настоящее время не обеспечивает будущим специалистам среднего звена готовность к трудовой деятельности. Многие выпускники не могут найти себе работу, определиться в современной экономической жизни. Поэтому страна должна разрешить свои назревшие социальные и экономические проблемы не за счет экономии на образовании, а на основе его развития. Модернизация среднего профессионального образования - это политическая и общенациональная задача, а формирование и развитие профессиональных компетенций является целью системы образования на современном этапе.

В этой связи необходимо отметить, что внедрение в систему формирования профессиональных компетенций специалистов среднего профессионального образования, ориентировано на удовлетворение: адекватных требований общества и производства в области подготовки специалиста соответствующего достаточно высокому уровню квалификации по профессиям, востребованным на рынке труда; требований потребителей образовательных услуг, обеспечивающих конкурентоспособность рынка труда; запросов образовательных учреждений по реализации потенциальных возможностей, связанных с повышением качества образования, удовлетворяющих социуму.

Это значит, что важнейшими критериями формирования профессиональных компетенций специалистов среднего профессионального образования является:

- соответствие содержания образования социальным и экономическим переменам общества;

- его соотношение с требованиями к информационной культуре личности; изменяющаяся парадигма образования;

- социальный заказ общества на подготовку конкурентоспособного специалиста;

- уровень развития педагогической науки.

\section{Литература}

1. Концепции модернизации Российского образования на период до 2010 года [Текст] // Бюллетень Минобразования России. - 2002. - № 2. 